\title{
Article \\ Effects of the FSW Parameters on Microstructure and Electrical Properties in Al 6061-T6- Cu C11000 Plate Joints
}

\author{
Daniel García-Navarro ${ }^{1}$, Juan Carlos Ortiz-Cuellar ${ }^{2}$, Jesús Salvador Galindo-Valdés ${ }^{2}$, Josué Gómez-Casas ${ }^{2}$, \\ Carlos Rodrigo Muñiz-Valdez ${ }^{2}$ and Nelly Abigaíl Rodríguez-Rosales ${ }^{1, *}$ \\ 1 Departamento de Metal Mecánica, Tecnológico Nacional de México/I.T. Saltillo, \\ 25280 Saltillo, Coahuila, Mexico; dnavarro@itsaltillo.edu.mx \\ 2 Facultad de Ingeniería, Universidad Autónoma de Coahuila, 25350 Arteaga, Coahuila, Mexico; \\ carlosortiz@uadec.edu.mx (J.C.O.-C.); s_galindo@uadec.edu.mx (J.S.G.-V.); jogomezc@uadec.edu.mx (J.G.-C.); \\ rodrigo.muniz@uadec.edu.mx (C.R.M.-V.) \\ * Correspondence: nrosales@itsaltillo.edu.mx
}

Citation: García-Navarro, D.; Ortiz-Cuellar, J.C.; Galindo-Valdés, J.S.; Gómez-Casas, J.; Muñiz-Valdez, C.R.; Rodríguez-Rosales, N.A. Effects of the FSW Parameters on Microstructure and Electrical Properties in Al 6061-T6- Cu C11000 Plate Joints. Crystals 2021, 11, 21. https://doi.org/10.3390/cryst11010021

Received: 9 December 2020

Accepted: 25 December 2020

Published: 29 December 2020

Publisher's Note: MDPI stays neutral with regard to jurisdictional claims in published maps and institutional affiliations.

Copyright: (c) 2020 by the authors. Licensee MDPI, Basel, Switzerland. This article is an open access article distributed under the terms and conditions of the Creative Commons Attribution (CC BY) license (https: / / creativecommons.org/ licenses/by/4.0/).

\begin{abstract}
Friction Stir Welding (FSW) is a feasible welding process to join dissimilar materials due to its solid-state nature. In this study the FSW of 6061-T6 aluminum with pure Cu plates was performed with the objective of evaluating the effects of the FSW parameters on the microstructure and electrical properties. The processing parameters (rotational and traverse speeds) were established to reduce the common defects in the friction-stir welding process. Therefore, the obtained results validated the better mechanical properties and a smaller increase of the electrical resistivity. The rotational speeds used were of 1000, 1150, and $1300 \mathrm{rpm}$, and the traverse speeds of 20,40, and $60 \mathrm{~mm} / \mathrm{min}$, with the purpose of varying the heat input of the process. The microstructural characterization revealed the presence of a mixture of aluminum and copper into the weld zone, along with copper particles and the formation of intermetallic compounds. It was found that the electrical resistivity of the joints ranged from 0.029 to $0.036 \mu \Omega$. The highest electrical resistivity values were obtained at the lowest traverse speed $(20 \mathrm{~mm} / \mathrm{min}$ ) and the lowest resistivity values were obtained at highest traverse speed $(60 \mathrm{~mm} / \mathrm{min})$.
\end{abstract}

Keywords: friction stir welding; aluminum; copper; dissimilar; electrical properties

\section{Introduction}

The dissimilar joint is of great interest due to the economic and technological advantages that it represents. However, any welding process is always difficult because materials have huge differences in mechanical and metallurgical properties. Materials as copper and aluminum have excellent electrical and thermal conductivities, and their joint are used in applications such as electrical connectors, bus-bars, foil conductors in transformers, capacitor and condenser foil windings, refrigeration tubes, heat-exchangers, etc. [1-3]. Friction Stir Welding (FSW) is a solid-state welding process, where similar and dissimilar materials can be joined through a mixture of heat created by friction and mechanical stirring of the materials in the joint line, using only a non-consumable rotatory tool between the plates. They are subjected firmly to avoid being expelled when the rotatory tool starts to move between the plates and making it one of the most common techniques for joining different materials, such as Al-Fe [4,5], Al-Mg [6], Al-Ti [7], and Al-Cu [8,9], where the chemical, physical, and thermal properties have a great influence on the heat generation during the welding process, the materials flow, and the final properties of the welding.

In FSW, weld properties and quality are controlled by the parameters of the process, such as tool rotational speed, traverse speed, geometry and materials of the tool, tool tilt angle, plunge depth, tool pin offset, and position of different base materials [10-13]. Within these, tool rotational speed and traverse speed are critical parameters that significantly affect the joint quality and are the ones responsible for the heat input that makes the 
welding process possible. An inappropriate selection of the mentioned parameters results in an insufficient plasticity of the materials, as well as in an unbalanced material movement around the tool pin, which in turn leads to defects such as voids, cracks, lack of penetration and pores $[1,12,13]$. In the literature, it is found that $\mathrm{Al}$ and $\mathrm{Cu}$ welds have been carried out using the friction stirring technique with the appropriate parameters.

Nidhi Sharma et al. [12] studied the effect of the pin profile in the material during stirring in FSW of AA5754-Cu pure, concluding that Al is more easily agitated and creates flow lines in the weld nugget, because is the softest material as well as they found out that cylindrical cam profiles result in defect free joining of Al-Cu mainly due to better stirring assisted pulsating action. S. Shankar et al. [13] studied the tool pin offset and the mechanical properties of the dissimilar joint of AA1050-Cu oxygen free by FSW to get a bus-bar with improved life and reduced maintenance cost. They showed that without a displacement of the tool resulted in cracks and holes in the stir zone, decreasing the mechanical properties; while with a tool offset of $1 \mathrm{~mm}$ to $\mathrm{Al}$ side resulted in a weld nugget composed of an Al matrix and a small fraction of copper, with adequate stirring of both materials.

However, despite of the ability to perform these joints, problems such as intercalated edges in the microstructure, formation of intermetallic compounds (IMCs) and fragmentary defects are still presented on this type of welding [12-15]. FSW of Al-Cu is susceptible to nucleation and growth of IMCs at temperatures greater than $120{ }^{\circ} \mathrm{C}[9,16,17]$. This technique is thermally activated by the increase in temperature; thus, nucleation and growth processes of IMCs are accelerated [18].

In some previous investigations, the effect of the FSW parameters on the microstructure and mechanical properties of the Al-Cu welded joint was studied. S. Khodir et al. [19] studied the effect of rotational speed and the IMCs on the microstructure of AA1050-Cu pure dissimilar FSW joints. They observed complex layered structures in the stir zone, that containing IMCs such as $\mathrm{Al}_{2} \mathrm{Cu}, \mathrm{Al}_{4} \mathrm{Cu}_{9}$, and their amount increased with increasing rotational speed from 100 to $1400 \mathrm{rpm}$. On the other hand, E. Ryl'kov, et al. [20] studied the shift of the tool toward aluminum and rotational speed on the microstructure of aluminum alloy $\mathrm{AlMg}_{5}-\mathrm{Cu} \mathrm{M} 1$ joints by FSW. Finding the formation of intermetallic compounds of up to $2 \mu \mathrm{m}$, also the content and the distribution of this particles depended on the mode of the FSW. These IMCs become stress concentrators and lower than the plastic properties of the welded joint. They concluded that the best parameters combination in relation to the mechanical properties was $1200 \mathrm{rpm}$ and $100 \mathrm{~mm} / \mathrm{min}$, for rotational speed and traverse speed, respectively, and tool offset of $2 \mathrm{~mm}$ to Al. The characteristics of these IMCs vary depending on the phase location and they are formed according to the Al-Cu phase diagram. The main IMCs found in $\mathrm{Al}-\mathrm{Cu}$ welding are $\mathrm{Al}_{2} \mathrm{Cu}, \mathrm{AlCu}$, and $\mathrm{Al}_{4} \mathrm{Cu}_{9}$, and their presence reduces the mechanical properties of the weld [18-21].

A high rotational speed forms a large quantity of IMCs, due to the increased heat input that is generated, and produces great stirring, which is responsible for separating the particles of the different base materials. Additionally, by increasing the rotational speed, a thickening of the IMCs is caused because of the heat input $[19,21]$. On the other hand, an extremely high traverse speed produces a joint with interfaces without being completely welded, resulting in the lack of heat input and an inadequate mixing of the materials to be joined, causing defects [19,22,23]. A low welding speed produces a large heat input and generates more IMCs [24-26]. With a high heat input, the material is greatly softened, resulting in turbulent flow of the plasticized material. Taking this into account, it is important to study the combination between the rotational and traverse speeds, controlled by heat input, and IMCs formation in FSW of dissimilar materials.

The union of aluminum and copper is presented in different electrical applications; however, if the terminals of the copper and aluminum electrical channels are connected to each other directly. That is, if only steel screws are used to make the connections between bars without an $\mathrm{Al} / \mathrm{Cu}$ bimetallic transition piece, the service life of the electrical connection is approximately of 1 year. Nevertheless, when welding the two $\mathrm{Al} / \mathrm{Cu}$ materials the useful 
life increases to more than 10 years. [27,28]. To learn about the effective level of benefit in producing $\mathrm{Al}$-busbar with $\mathrm{Cu}$ ends, as well as to evaluate the electrical properties of the FSW Al-Cu and bimetallic component Al-Cu, Ólafsson et al. [29] investigated the benefits of having an $\mathrm{Al}$ busbar with welded $\mathrm{Cu}$ ends to evaluate the force relaxation phenomena of a pre-loaded bolt joint on $\mathrm{Cu}$ versus $\mathrm{Al}$, under cyclic thermal loading simulating a busbar connection while in operation. The weld resulted in $85 \%$ tensile strength efficiency compared to the $\mathrm{Al}$ base material, and $97 \%$ electrical conductivity efficiency compared to an ideal bimetallic component made of the same materials with no contact resistance. Electrical resistance of the FSW was 200 times lower than the electrical contact resistance between the Al-Cu materials while under high compressive force.

The effect of various FSW parameters during joining of Al-Cu has been reported, but limited literature is available on relation on electrical properties. Eslami et al. [30] studied the electrical properties of FSW to AA 1050-Cu CW008A. The joints were manufactured at a comparatively high traverse speed and low rotational speed, $500 \mathrm{~mm} / \mathrm{min}$ and $600 \mathrm{rpm}$, respectively. It found the average electrical resistance of the joints was $0.01155 \mathrm{~m} \Omega$ and was between the electrical resistances of the base materials used.

In this study, the FSW of 6061-T6 Al plates with pure Cu plates was carried out varying the parameters of the process to analyze the heat input ratio during the process and their effect on the microstructure and the formation and growth of IMCs that impact on the electrical properties of the joint.

\section{Materials and Methods}

With the objective to set the parameters during the FSW, several experiments were carried out to get visually sound welds. In this study, plates of AA 6061-T6 and C11000 were joined by FSW using a conventional milling machine (JIH FONG, JIH FONG MACHINERY CO., Fengyuan, Taichung, Taiwan) in a lap configuration. The plates dimensions were $100 \mathrm{~mm} \times 50.8 \mathrm{~mm} \times 3 \mathrm{~mm}$ and a two combination set of each parameter were selected. This is shown in Figure 1, moreover, Table 1 presents the chemical composition of both materials according to manufactured data.
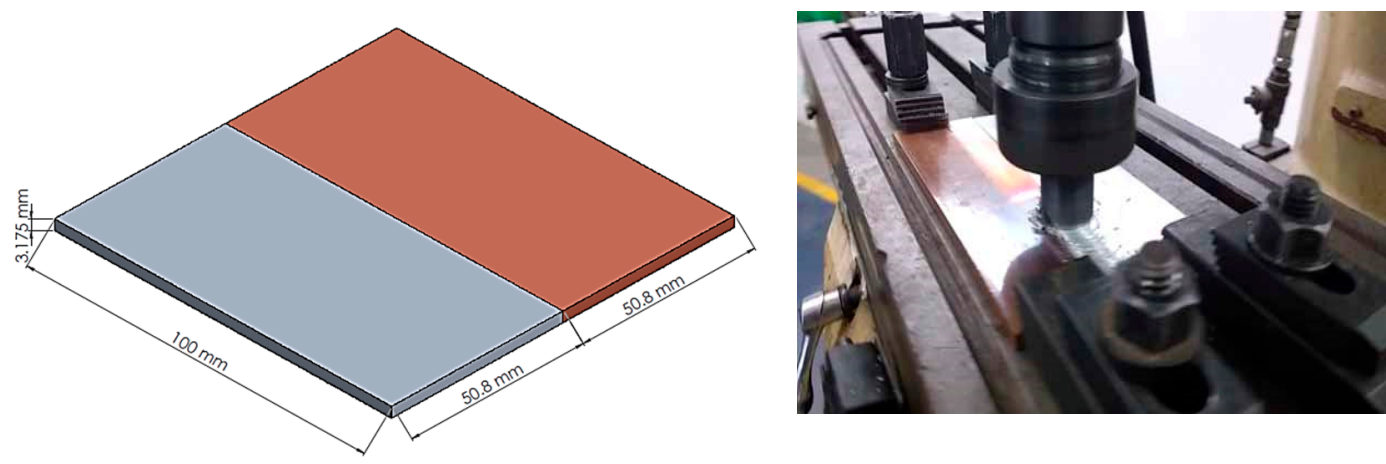

Figure 1. Dimension and configuration of Al6061-T6 and C1100 plates to be weld.

Table 1. Chemical composition of base materials.

\begin{tabular}{cccccccc}
\hline Element & Al & Cu & Fe & Cr & Mg & Zn & Si \\
\hline A6061-T6 & Bal. & 0.38 & 0.57 & 0.33 & 1.12 & 0.25 & 0.53 \\
$\mathrm{Cu}$ & - & 99.9 & - & - & - & - & - \\
\hline
\end{tabular}

The copper plate was positioned in the advancing side and the aluminum alloy plate in the retreating side, with a $2 \mathrm{~mm}$-displacement of the rotatory tool to the aluminum side. A D2 steel was used in the rotatory tool with a 4.5:1 shoulder/pin diameter relationship with a height pin of $2.8 \mathrm{~mm}$. Before the welding, the rotatory tool was heat treated at $1100{ }^{\circ} \mathrm{C}$ followed by a reheating at $300^{\circ} \mathrm{C}$ to obtain a $56 \mathrm{HRC}$ hardness. Figure 2a shows 
the welding configuration and in Figure $2 \mathrm{~b}$ the rotating tool design used in the present investigation.

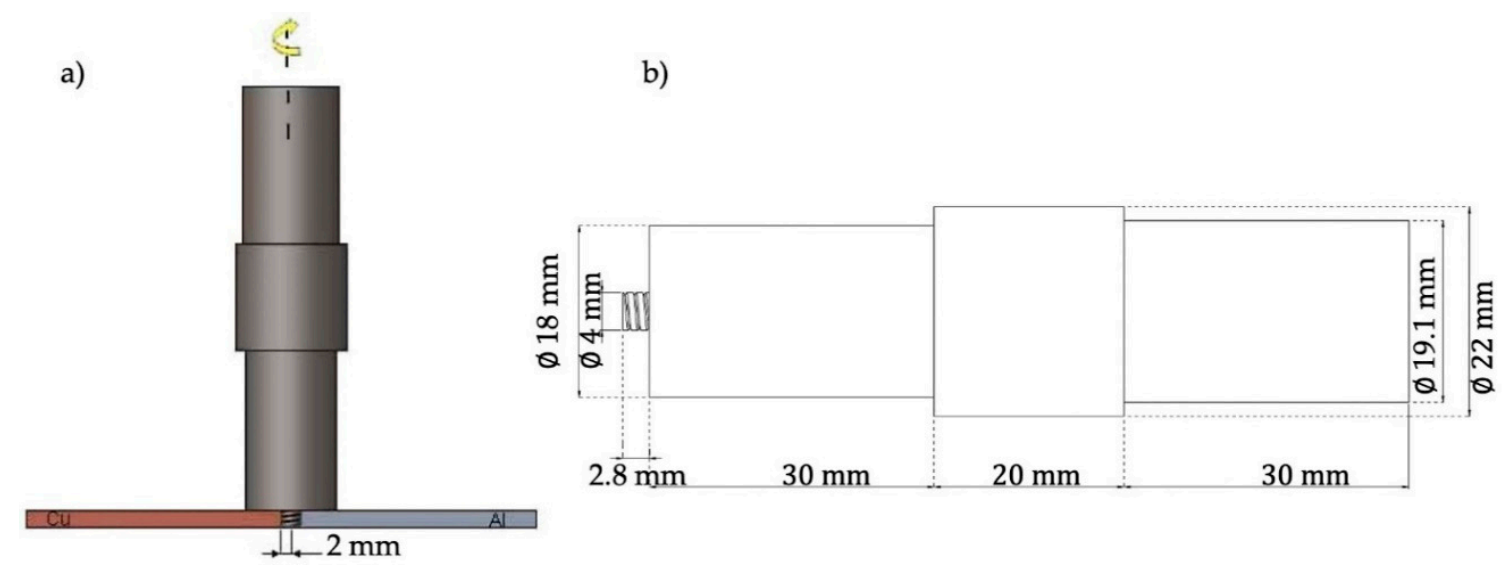

Figure 2. Schematic diagram of Friction Stir Welding (FSW) process. (a) configuration of the weld, (b) tool design.

The rotational speed was of 1000, 1150, and $1300 \mathrm{rpm}$ and the traverse speed of 20, 40, and $60 \mathrm{~mm} / \mathrm{min}$. The thermographic images were captured with a FLIR E40 thermographic camera to determine the heat input during welding. The different combinations of the parameters are presented in Table 2.

Table 2. Different combination of parameters in the FSW of 6061-T6 and C11000 plates.

\begin{tabular}{|c|c|c|}
\hline Sample & Rotational Speed (rpm) & Traverse Speed $(\mathrm{mm} / \mathrm{min})$ \\
\hline S1000-20 & \multirow{3}{*}{1000} & 20 \\
\hline S1000-40 & & 40 \\
\hline S1000-60 & & 60 \\
\hline S1150-20 & \multirow{3}{*}{1150} & 20 \\
\hline S1150-40 & & 40 \\
\hline S1150-60 & & 60 \\
\hline S1300-20 & \multirow{3}{*}{1300} & 20 \\
\hline S1300-40 & & 40 \\
\hline S1300-60 & & 60 \\
\hline
\end{tabular}

After the welding was completed, the samples were sectioned at different parts. The sections with a length of $30 \mathrm{~mm}$ are 1 and 4 , respectively. The sections with a length of $20 \mathrm{~mm}$ are 2 and 3, respectively. Figure 3 shows the sectioned parts in a complete welding process.

In order to eliminate unstable effects during the start and end stages of the FSW process, only Sections 2 and 3 were rectified and polished stages. First, the sectioned samples were rectified using $\mathrm{SiC}$ papers and water as lubricant, in the sequence of grain size: $80,220,320,400,600,800,1200$. The polish was performed using a $3 \mu \mathrm{m}$ diamond paste, then $1 \mu \mathrm{m}$ and $0.3 \mu \mathrm{m}$ alumina, and finally with a $0.25 \mu \mathrm{m}$ diamond paste and $0.02 \mu \mathrm{m}$ colloidal silica to obtain a mirror finish. The samples were rinsed with water and then cleaned with acetone in an ultrasound during $10 \mathrm{~min}$. 


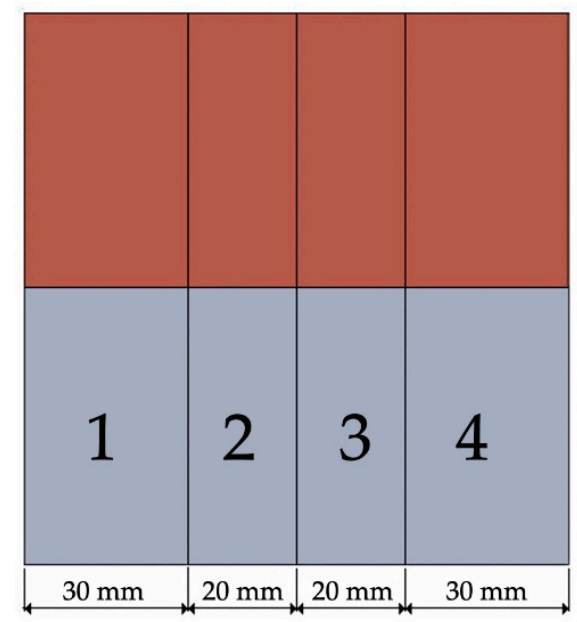

Figure 3. Schematic representation of weld samples.

The electrical properties of the joints were studied for the different conditions of the experiments, the electrical resistance was evaluated with a low resistance digital ohmmeter (DLRO 10X, resolution of $0.1 \mu \Omega$ and with an accuracy of $\pm 2 \%$ ), all measurements were performed at room temperature and at a constant contact pressure of the ohmmeter wires with each sample and the measurements were taken every $5 \mathrm{~mm}$ towards the base of the material, starting from the joint line of the sections of welds 2 and 3, as shown in Figure 4 .

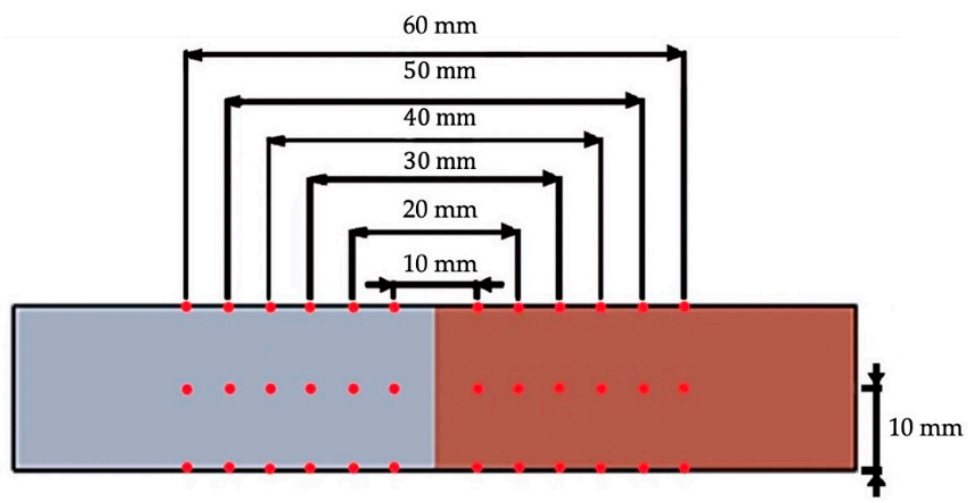

Figure 4. Schematic electrical resistance measurements in plates joined.

From the measurement of electrical resistance, the resistivity of each sample was calculated according to Equation (1), where $\rho$ is the electrical resistivity $(\Omega \cdot \mathrm{m}), R$ is the resistance $(\Omega), A$ is the cross-sectional area $\left(\mathrm{m}^{2}\right)$, and $l$ is the length of the sample $(\mathrm{m})$.

$$
\rho=R\left(\frac{A}{l}\right)
$$

With the calculation of the electrical resistivity, the electrical conductivity of each sample was determined according to Equation (2), where $\sigma$ is the electrical conductivity $\left(\Omega^{-1} \mathrm{~m}^{-1}\right)$.

$$
\sigma=\frac{1}{\rho}
$$

To reveal the microstructural features of the dissimilar welding, etching was performed on the polished samples with Flicks reagent in the aluminum side during $15 \mathrm{~s}$, while a solution with a chemical composition of $100 \mathrm{~mL}$ of water, $50 \mathrm{~mL}$ of $\mathrm{HCl}$ and $5 \mathrm{~g}$ of $\mathrm{Fe}_{3} \mathrm{Cl}$, was applied for the copper side during $25 \mathrm{~s}$. The samples were observed by Scanning Electron Microscopy (SEM, JEOL USA, Inc., Pleasanton, CA, USA). In addition, a semiquantitative analysis was performed by Energy-dispersive X-ray Spectroscopy (EDS, JEOL 
USA, Inc., Pleasanton, CA, USA) on the particles found in the weld area, with the purpose of identifying the IMCs present and measuring their thickness.

With an X-ray diffractometer, Empyrean model, Panalytical brand, the IMCs present in the weld zone were identified. The XRD analysis was carried out using a range from 15 to $100^{\circ}$ with a step size of $0.026^{\circ}$, and with a voltage of $40 \mathrm{kV}$ and an electrical current of $30 \mathrm{~mA}$. The analyzed samples were cut to a size of $18 \times 10 \times 3.175 \mathrm{~mm}$, rectified, and polished using the same procedure mentioned above.

\section{Results and Discussion}

\subsection{Effect of Welding Parameters on the Heat Production on the Surface}

A heat input change was performed in FSW using different parameters, tool rotational speed and traverse speed, which ranged from 1000 to $1300 \mathrm{rpm}$ and from 20 to $60 \mathrm{~mm} / \mathrm{min}$, respectively. The measurements of the changes in temperature, produced by the variation of the parameters, were carried out by thermographic analysis. Figure 5 shows the maximum surface temperature profiles obtained in each welding condition, between the tool and the base materials. It can be observed that the highest temperatures are obtained during the lowest traverse speed for any rotational speed. This is due to the increased contact time between the rotary tool and the surface of the workpieces. A slow rotational speed avoids that the weld zone reaches the appropriate temperature with enough plastic deformation, due to the lack of heat input. The weld zone cannot be properly plasticized and, consequently, the material flow is inadequate, which will generate defects, especially macrocracks and gap defects in the weld zone. With the increase in heat input, the movement of the tool through the joint line of the workpieces is facilitated. Some studies of different systems of Al-Cu by FSW have found a change in the heat input when varying the rotational speed and traverse speed. Some researchers like Xue, Barekatain, and Wiedenhoft $[25,31,32]$ reported that tool rotational speed is the main responsible for the heat input. However, other authors such as Muthu and Saeid [27,33] consider that the traverse speed is important in the heat distribution over the joint. In the present work, both parameters affect the heat input, higher temperatures associated with higher rotational speed; however, the greatest changes in temperature are observed at the change of traverse speed at the same rotational speeds.

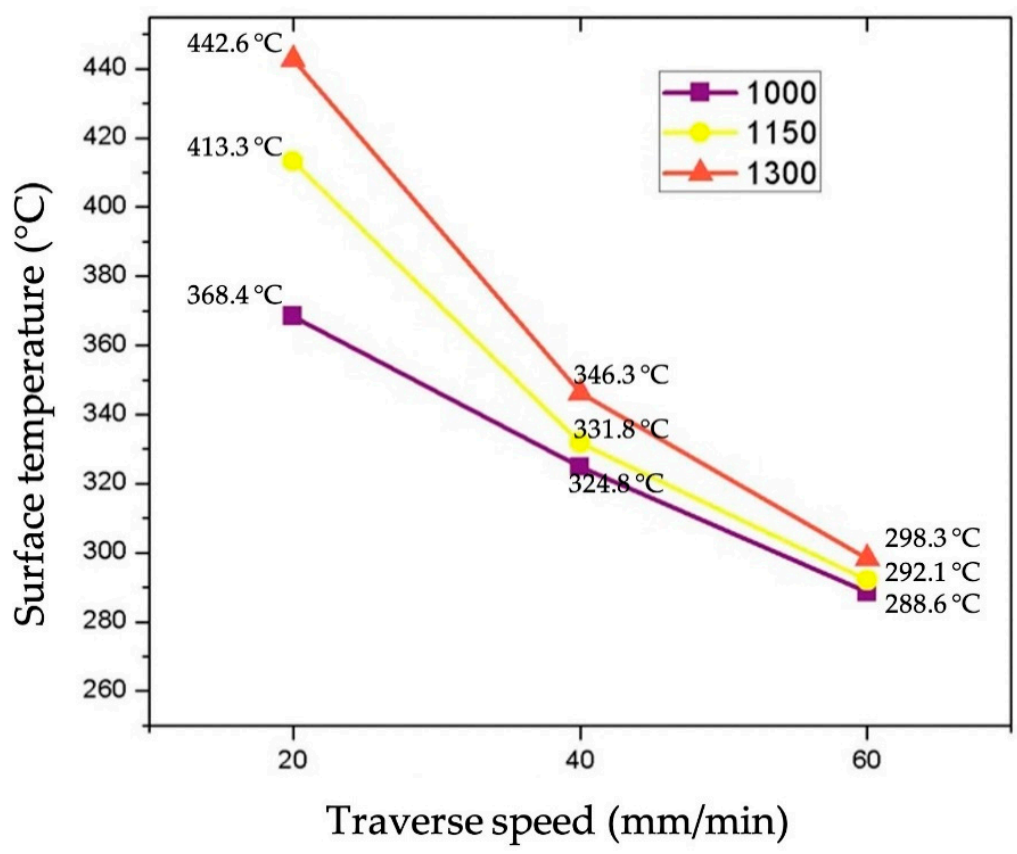

Figure 5. Maximum surface temperature profiles of different condition of welding. 
Temperature profile as a function of the welding length is presented in Figure 6. The surface temperature measurement started at the same time the rotatory tool was immersed into the line joint of the plates to realize the welding. So, it was assumed a $100 \mathrm{~mm}$ as a total distance of the welding. It can be observed that temperature raises as welding is carried out, in addition to the tendency of the temperature stabilization at the end of the welding. This is due to the sufficient energy that was already reached for the nucleation of new grains, which recrystallized stress-free, and only grain growth occurs by generation of adiabatic heat. For welding with higher heat input, such as those made at $20 \mathrm{~mm} / \mathrm{min}$, a greater amount of IMCs and their thickening is expected. This is due to the nucleation and growth processes of IMCs are thermally activated by the increase in temperature [9,16-18]. So, it is assumed that heat input in the FSW of $\mathrm{Al}-\mathrm{Cu}$ is controlled by the relation between rotational speed and traverse speed, which in turn impacts the microstructure and properties of joints.

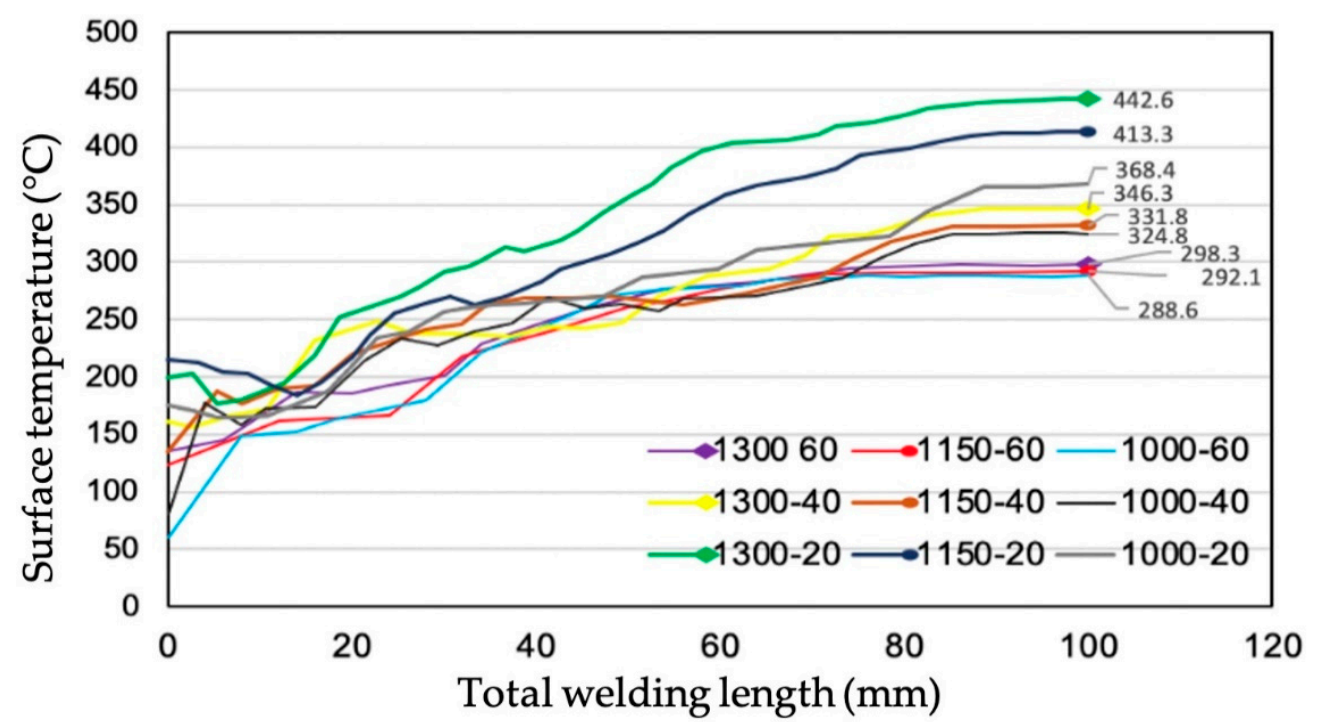

Figure 6. Temperature profile as a function of the welding length.

\subsection{Microstructure Analysis}

Samples were analyzed in the scanning electron microscope, and it was possible to verify that all the samples exhibit the typical three types of microstructures of the process, the dynamically recrystallized zone or nugget (DXZ), the thermomechanically affected zone (TMAZ) and the heat affected zone (HAZ) that surrounds the outer edges of the TMAZ. SEM images in the backscatter mode were taken from different zones of the sample 1000_40 and are presented in Figure 7.

In Figure $7 \mathrm{a}$ it is observed that DXZ is characterized by a mixture of non-homogeneous layers of both base metals, $\mathrm{Al}$ and $\mathrm{Cu}$. In the present investigation the typical structure of onion rings was not present, and a pattern of flow lines only formed semicircles. The onion rings structure its usually found in similar FSW; however, some researchers have found this structure in FSW of Al-Cu $[8,14,32,34]$. The present structure can be attributed to weld configuration, where the pin tool was inserted into the Al-side instead of on the joint line between base materials, due their difference in melting temperature, the mixing of $\mathrm{Cu}$ particles in $\mathrm{Al}$ matrix was difficult. Likewise, in Figure 7c,d the fragmentation of different particle sizes is observed in the flow lines of the TMAZ on both sides, larger copper particles being observed on the Al-side than on the $\mathrm{Cu}$-side because the deformation process generated for the rotatory tool. The mixture of these irregular $\mathrm{Cu}$ particles in $\mathrm{Al}$, form IMCs such as $\mathrm{CuAl}_{2}, \mathrm{Cu}_{9} \mathrm{Al}_{4}, \mathrm{Cu}_{3} \mathrm{Al}$, and $\mathrm{CuAl}$ [9,16-18]. HAZ Cu-side (Figure 7b) also shows a particle distribution probably because rotatory tool action and the metal that rounds the pin, while in the HAZ Al-side only occurs a grain growth. The rest of the 
samples show a similar distribution in their microstructures as presented in Figure 7, as it can be seen in Figure 8 for all welding conditions.
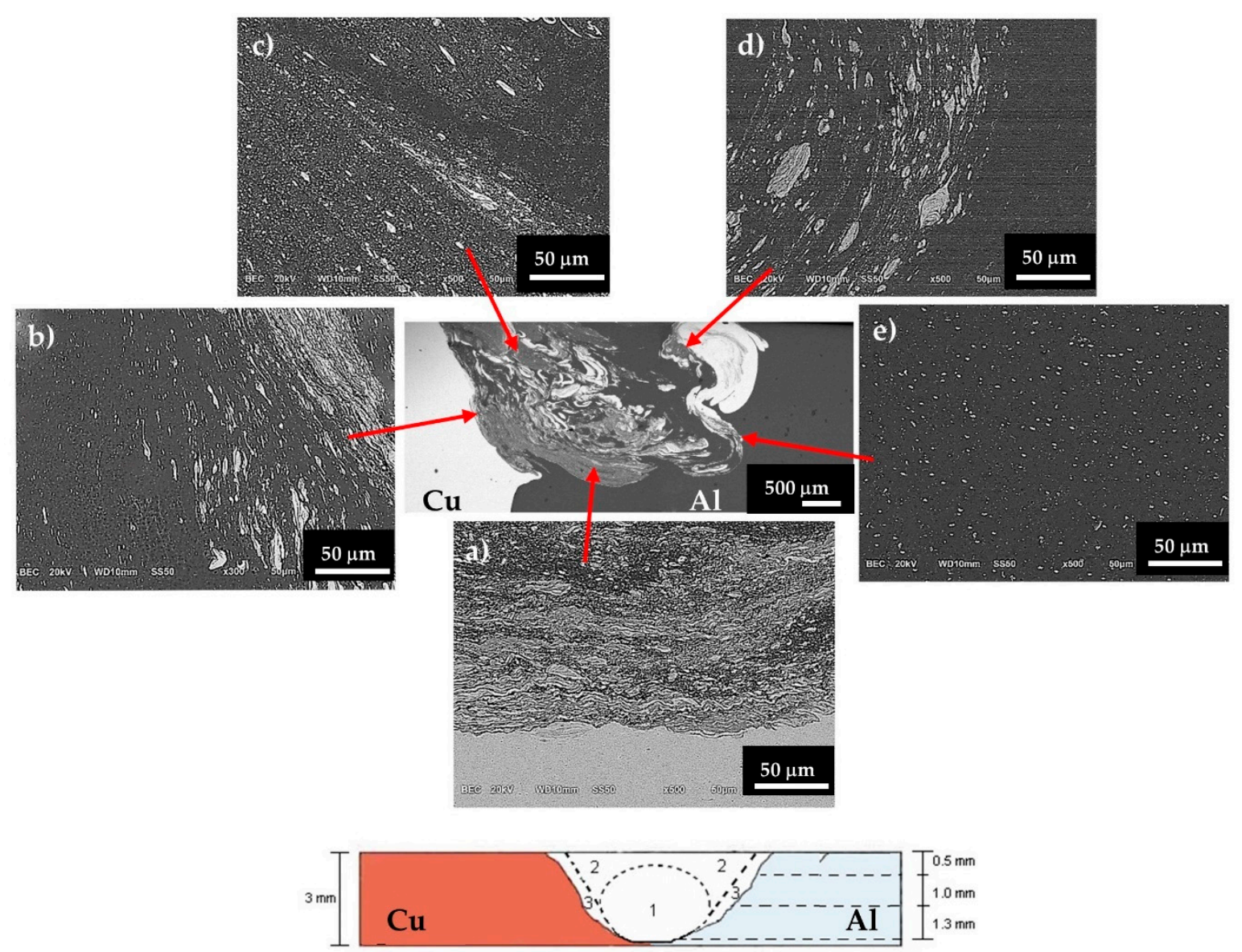

Figure 7. SEM micrographs of the cross section of the sample 1000_40. (a) nugget zone (DXZ), (b) heat affected zone (HAZ) Cu-side, (c) thermomechanically affected zone (TMAZ) Cu- side, (d) TMAZ Al-side, (e) HAZ Al-side.
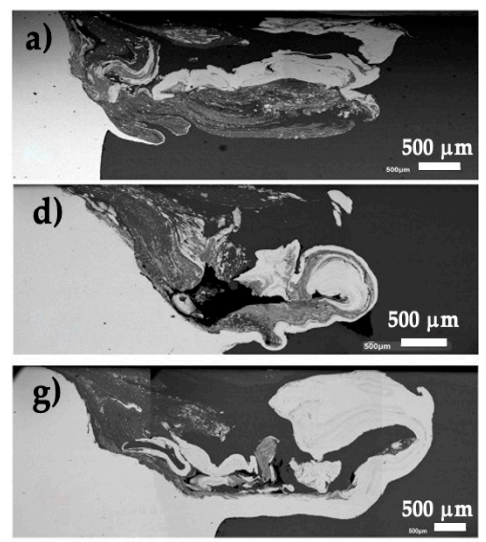

Figure 8. SEM microstructures of weld zones for all the Al-Cu FSW samples. (d) 1150_20, (e) 1150_40, (f) 1150_60, (g) 1300_20, (h) 1300_40, (i) 1300_60.
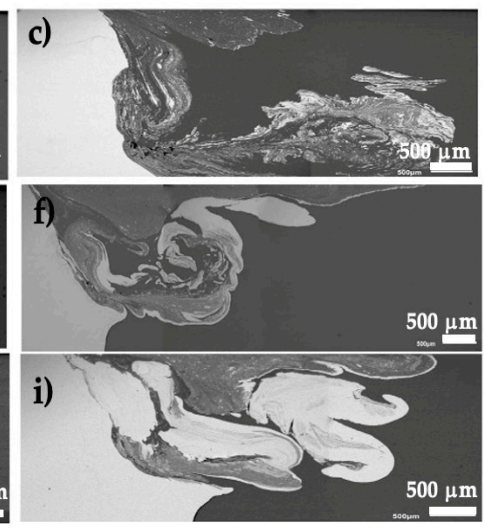

Figure 8 shows the microstructures for the different welding conditions, all having in common an Al matrix, alternating layers of aluminum and copper dispersed throughout the nugget. Alike, the flow pattern is different for every welding condition, by increasing the temperature during the welding process influences the material flow and, consequently, 
the welding quality. It is important to mention that there is no repetitive in the mixture of the two materials within the weld nugget, due to rotating the tool, the pin is dragging material around it and depositing it both in front of and behind it, which causes that different vortices appear for different welding conditions. It is important to mention, that there is no repeating pattern in the two materials mixture within the weld zone. That means, when the rotatory tool starts its movement, the pin is dragging material around it and deposits it both in front of and behind it, which causes different vortices, as shown in the different welded areas in Figure 8.

On the other hand, void defects are found in samples 1150_20 ( 980 $\mu \mathrm{m})$ and 1300_20 $(\sim 570 \mu \mathrm{m})$; this defect is shown in Figure 8d,g. These voids were formed under low traveled speed in combination with high rotational speeds. It is common to find the formation of defects in minor displacements due to high heat input; this causes the material to be greatly smoothed, resulting in a turbulent plasticized material flow. Different authors, such as Kush, Muthu, Saeid, and Sharma $[1,27,33,35]$, have found similar behavior in FSW of $\mathrm{Al}-\mathrm{Cu}$, when reducing the traverse speed, the heat input is increased, which later affects the metallurgical union and the mixture of $\mathrm{Cu}$ materials in an $\mathrm{Al}$ matrix, resulting in a large amount of IMCs formed as well as voids or tunnel defects.

The measurements of the changes in temperature during FSW showed that surface temperature range was between $290-440{ }^{\circ} \mathrm{C}$. According to the $\mathrm{Al}-\mathrm{Cu}$ phase diagram the possible intermetallic formed at these temperatures are $\mathrm{Al}_{2} \mathrm{Cu}, \mathrm{AlCu}, \mathrm{Al}_{2} \mathrm{Cu}_{3}$, and $\mathrm{Al}_{4} \mathrm{Cu}_{9}$. The $\mathrm{wt}^{\mathrm{O}} \% \mathrm{Cu}$ for each IMC of the Al-Cu binary phase diagram [36] is presented in Table 3. Based on the results of the $\mathrm{wt} \% \mathrm{Cu}$ and the relationship of these values to the phase diagram, it is possible to define the IMCs present in the welding area.

Table 3. $w \mathrm{t} \% \mathrm{Cu}$ in intermetallic compounds (IMCs) according to Al-Cu phase diagram [36].

\begin{tabular}{ccc}
\hline Phase & Range of $\mathbf{w t} \%$ of $\mathbf{C u}$ & Chemical Formula \\
\hline$(\mathrm{Al})$ & $0-5.56$ & $\mathrm{Al}$ \\
$\Theta$ & $52.5-53.7$ & $\mathrm{Al}_{2} \mathrm{Cu}$ \\
$\eta 1$ & $70-72.2$ & $\mathrm{AlCu}$ \\
$\eta 2$ & $70-72.2$ & $\mathrm{AlCu}$ \\
$\zeta 1$ & $74.4-77.8$ & $\mathrm{Al}_{3} \mathrm{Cu}$ \\
$\zeta 2$ & $74.4-75.2$ & $\mathrm{Al}_{3} \mathrm{Cu}_{4}$ \\
$\Delta$ & $77.4-78.3$ & $\mathrm{Al}_{2} \mathrm{Cu}_{3}$ \\
$\gamma 0$ & $77.8-84$ & $\mathrm{Al}_{4} \mathrm{Cu}_{9}$ \\
$\gamma 1$ & $79.7-84$ & $\mathrm{Al}_{4} \mathrm{Cu}_{9}$ \\
$\beta 0$ & $83.1-84.7$ & $\mathrm{AlCu}_{3}$ \\
$\mathrm{~B}$ & $88.5-89$ & $\mathrm{AlCu}_{3}$ \\
\hline
\end{tabular}

The IMCs appeared in different zones of the cross section of all samples, and with a SEM and EDS analysis, it was possible to determine the morphology of each intermetallic. The formation of IMCs was found, such as $\mathrm{Al}_{2} \mathrm{Cu}, \mathrm{AlCu}, \mathrm{Al}_{2} \mathrm{Cu}_{3}$, and $\mathrm{Al}_{4} \mathrm{Cu}_{9}$. The IMC that was present in the highest quantity, in all the welding conditions, was $\mathrm{Al}_{2} \mathrm{Cu}$, that requires the lowest activation energy for its precipitation, while the IMC with the lowest quantity was $\mathrm{Al}_{4} \mathrm{Cu}_{9}$., that requires the highest activation energy for its precipitation [18,36]. In most of the investigations carried out by different authors find the IMCs $\mathrm{Al}_{2} \mathrm{Cu}$ and $\mathrm{AlCu}$ [16-20].

On the other hand, the regions with the greatest number of IMCs were TMAZ Cu-side and weld zone, for any welding condition. Additionally, the areas with the least IMCs presence were the ones closest to the $\mathrm{Al}$ (HAZ and TMAZ Al-side). This is due to the tool setting offset of $2 \mathrm{~mm}$ to the Al-side, which reduces the possibility of finding large amounts of copper in the TMAZ or HAZ regions on the Al side. Moreover, IMCs were found in different proportions in the transverse part of the weld, being more present in the lower part, followed by the middle part and lastly in the upper part. This is assumed to occur because the entire body of the rotary tool is in direct contact with the workpieces thickness exhibiting the greatest amount of deformation, and thus, the highest temperature 
within the welding process. In the upper part, the heat input is lower, since heat is only generated by the friction of the shoulder of the rotary tool and the part, so the presence of IMCs is minor.

The thickness of the intermetallic layer varies from 0.16 to $2.14 \mu \mathrm{m}$. The values for each measurement of IMCs change depending on the zone in which they are located and on the welding condition. The average thickness of the IMCs is $0.66 \mu \mathrm{m}$. This average thickness of the IMCs is relatively low compared to other works. Muthu [27] studied the effect of tool travel speed on the microstructure of the FSW of Al-Cu. Their discovered that optimizing the heat input (increasing traverse speed) reduces the thickness of the IMC $\left(\mathrm{Al}_{2} \mathrm{Cu}\right.$ and $\left.\mathrm{Al}_{4} \mathrm{Cu}_{9}\right)$ from 3.4-1.7 $\mu \mathrm{m}$. Figure 9 shows the average thickness of the intermetallic layer for the different welding conditions. The thickest layers of IMCs were found in the samples where a traverse speed of $20 \mathrm{~mm} / \mathrm{min}$ was used, and these samples are the ones that reached the highest temperatures during the welding process. Therefore, it can be concluded that, at a higher traverse speed, the thickness of the intermetallic layer presents less variation as the rotational speed tool increases.

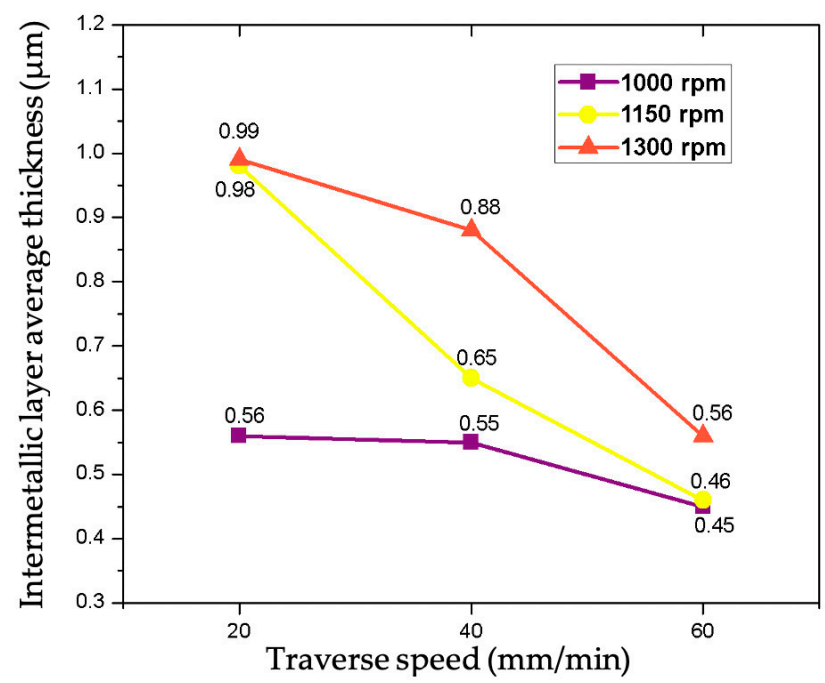

Figure 9. Influence of tool rotational speed and traverse speed on the average thickness of the intermetallic layer.

The morphology of the IMCs, such as $\mathrm{Al}_{2} \mathrm{Cu}, \mathrm{AlCu}, \mathrm{Al}_{4} \mathrm{Cu}_{9}$ and $\mathrm{Al}_{3} \mathrm{Cu}$, can be observed in Figures 10-12, respectively. $\mathrm{Al}_{2} \mathrm{Cu}$ and $\mathrm{AlCu}$ are found together, as it can be seen in the sample 1150_20 in Figure 10. An alternate layer can be observed from one base metal to another, where the whitest zones belong to $\mathrm{AlCu}$ surrounded by $\mathrm{Al}_{2} \mathrm{Cu}$. $\mathrm{As}^{\mathrm{Al}}{ }_{2} \mathrm{Cu}$ is the first reaction product, it is found all over in the weld zone, at all combinations of rotational and traverse speeds. According to literature [37-40], these two IMCs together are common.

In Figure 11, $\mathrm{Al}_{4} \mathrm{Cu}_{9}$ particles are observed in the sample 1000_40, which appear more frequently in the areas close to both base materials. Moreover, Figure 12 shows $\mathrm{Al}_{3} \mathrm{Cu}_{4}$ particles in the sample 1000_20 and only in the regions close to $\mathrm{Cu}$, since $\mathrm{Al}_{3} \mathrm{Cu}_{4}$ is not one of the first IMCs to form and requires a higher activation energy, it is common to find it in welds with a medium-high temperature $\left(325-440{ }^{\circ} \mathrm{C}\right)$ during FSW. 


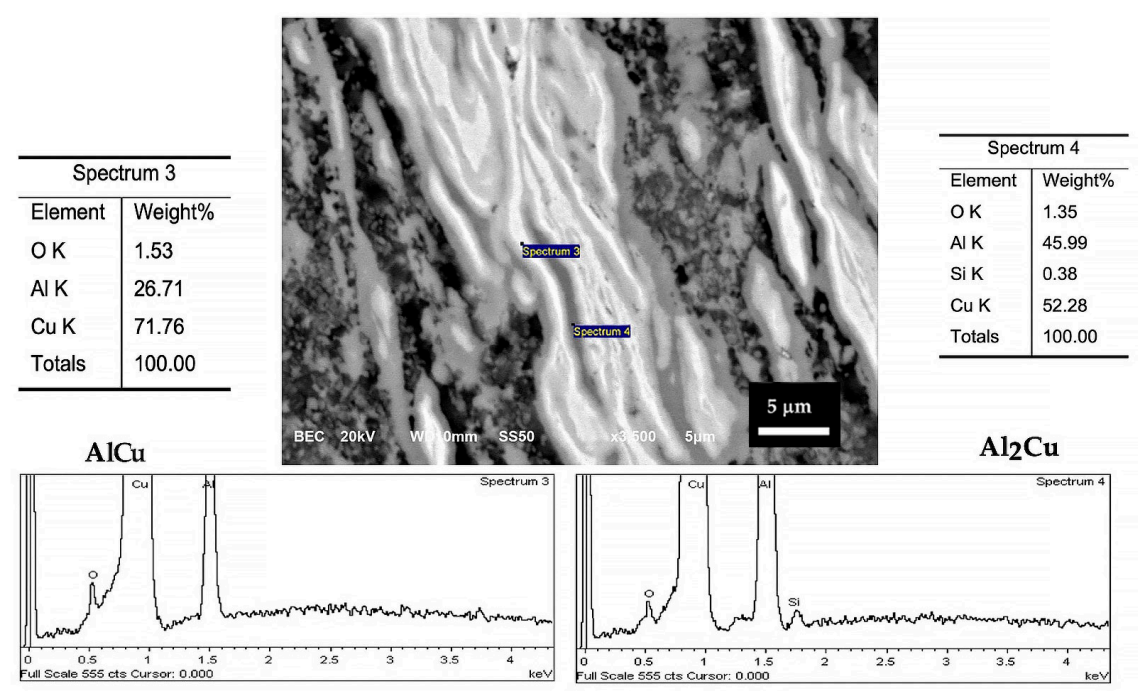

Figure 10. SEM micrographs and Energy-dispersive X-ray Spectroscopy (EDS) of $\mathrm{AlCu}$ and $\mathrm{Al}_{2} \mathrm{Cu}$, found in weld zone of FSW Al6061-Cu, performed at $1150 \mathrm{rpm}$ and $20 \mathrm{~mm} / \mathrm{min}$.

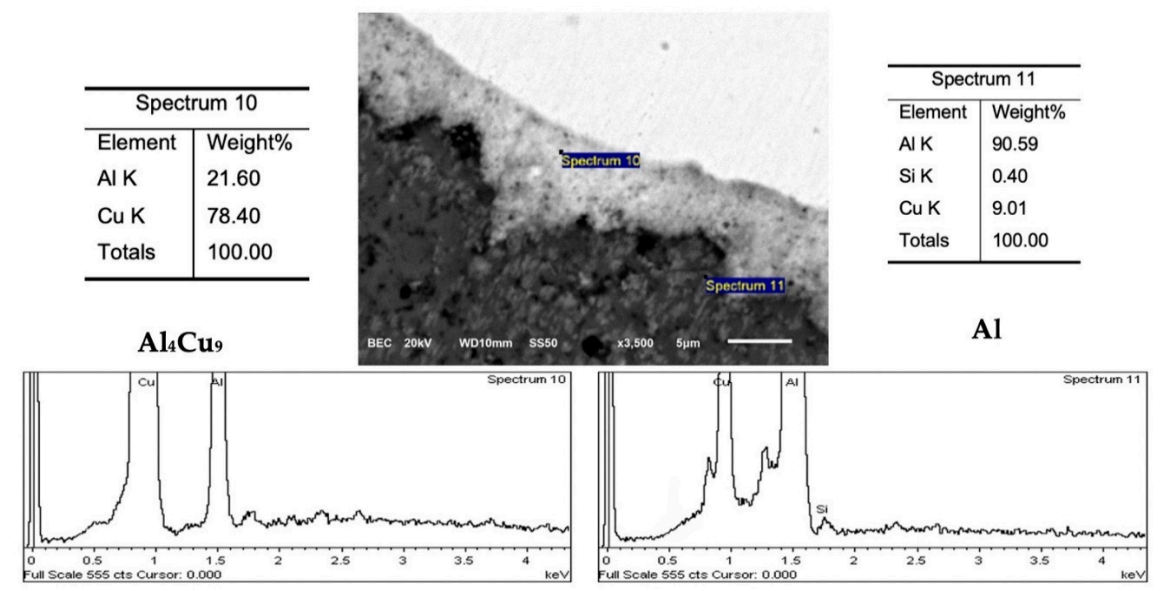

Figure 11. SEM micrographs and EDS of $\mathrm{Al}_{4} \mathrm{Cu}_{9}$ found close to the aluminum of base material, the FSW Al6061-Cu was performed at $1000 \mathrm{rpm}$ and $40 \mathrm{~mm} / \mathrm{min}$.
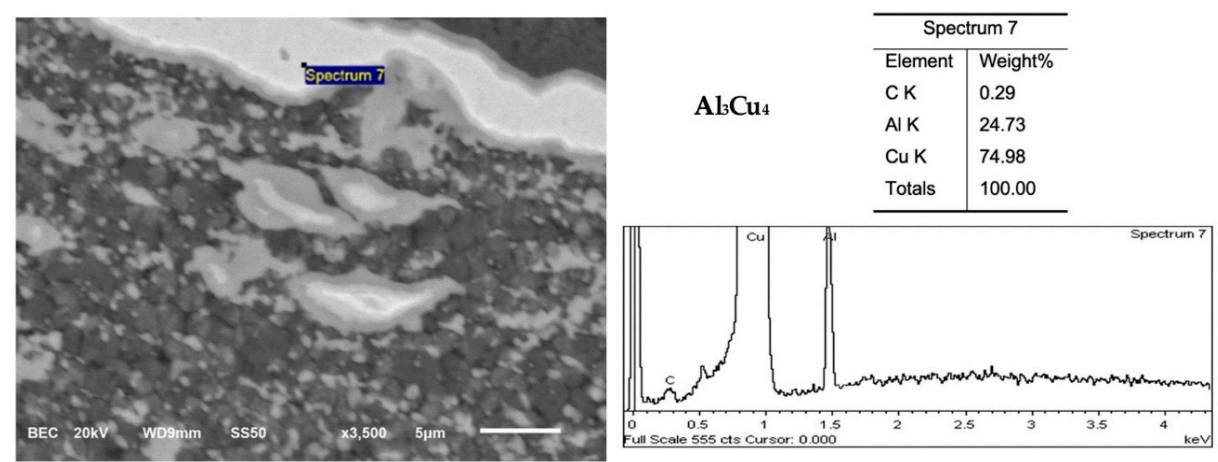

Figure 12. SEM micrographs and EDS of $\mathrm{Al}_{3} \mathrm{Cu}_{4}$ found close to the aluminum of base material, the FSW Al6061-Cu was performed at $1000 \mathrm{rpm}$ and $20 \mathrm{~mm} / \mathrm{min}$.

The morphology of these IMCs was identified using SEM and EDS analysis, and the phase composition was determined by XRD. Figure 13 shows the diffraction patterns obtained for the samples with 1000, 1150 and $1300 \mathrm{rpm}$, at different traverse speeds, respectively. The peaks corresponding to the IMCs were weak in all the joints, due to 
the low quantities of the IMCs formed. It is observed that the most common IMCs in the union of $\mathrm{Al}$ and $\mathrm{Cu}$ are $\mathrm{Al}_{2} \mathrm{Cu}$ and $\mathrm{AlCu}$ since they are present in all welding parameters. This is because they present the minimum activation energy. In the samples obtained at $60 \mathrm{~mm} / \mathrm{min}$, less intensity is observed in the intermetallic peaks, because these samples reached lower temperatures $\left(288-298^{\circ} \mathrm{C}\right)$ during the process, compared to the other traverse speeds. These temperatures are not high enough to favor the formation of IMCs. This confirms the EDS results and the intermetallic thickness.
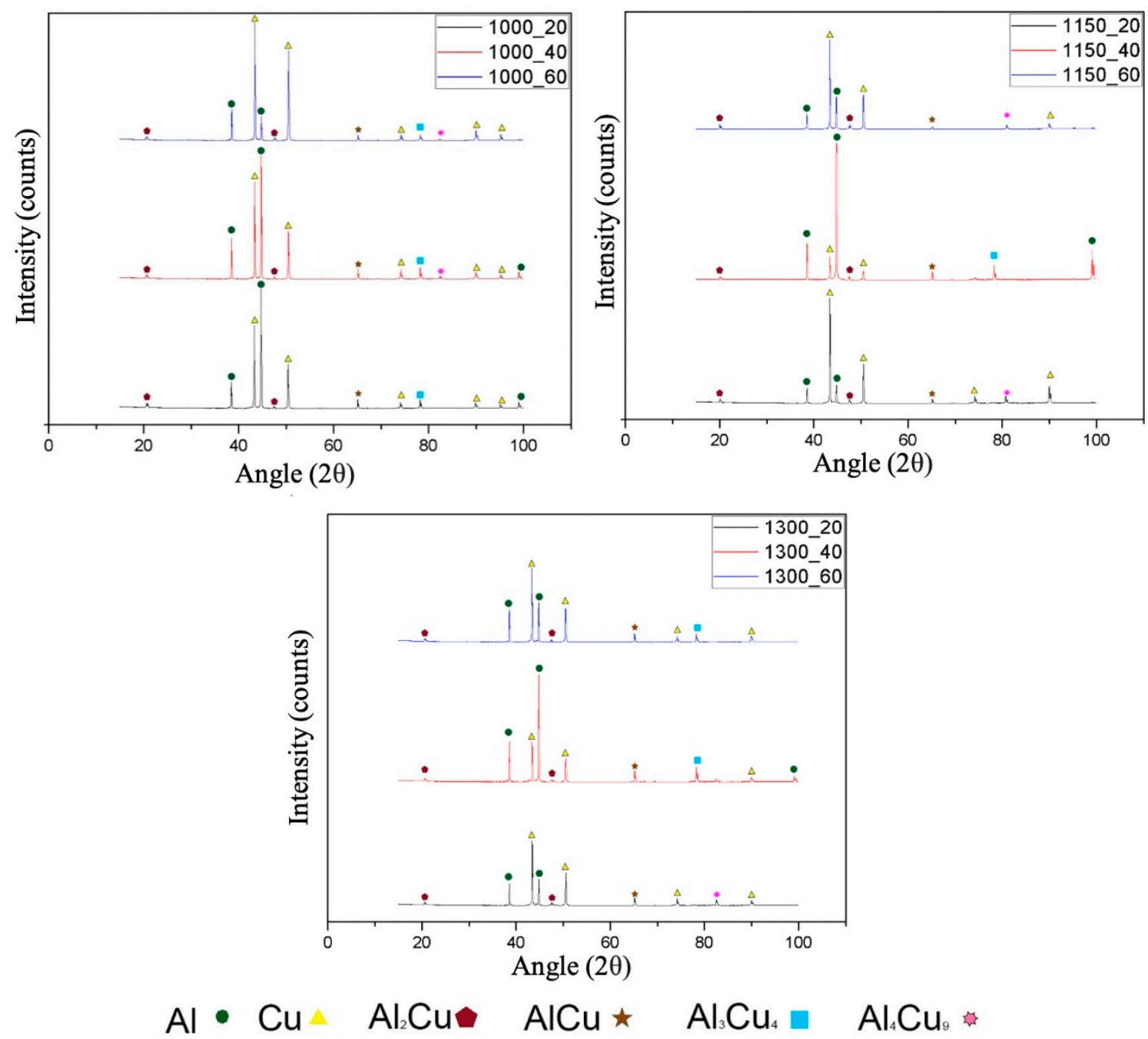

Figure 13. X-ray diffraction patterns of FSW AA 6061-C11000 plates at different welding parameters combination.

\subsection{Influence of IMC on Electrical Resistivity and Conductivity}

The electrical resistance to Al6061-Cu C11000 joint in all welding conditions was measured (144 measurements for each welding conditions) with a low resistance digital ohmmeter and the resistivity was calculated according to Equation (1). They were found in the electrical resistance measurements for the different welding conditions. The average electrical resistivity values are presented in Figure 14. It is observed that the electrical resistivities of the welds ranged between 0.029 and $0.036 \mu \Omega$. These changes in resistivity were due to differences in heat input, material flow, microstructure, and defects present in each weld. 


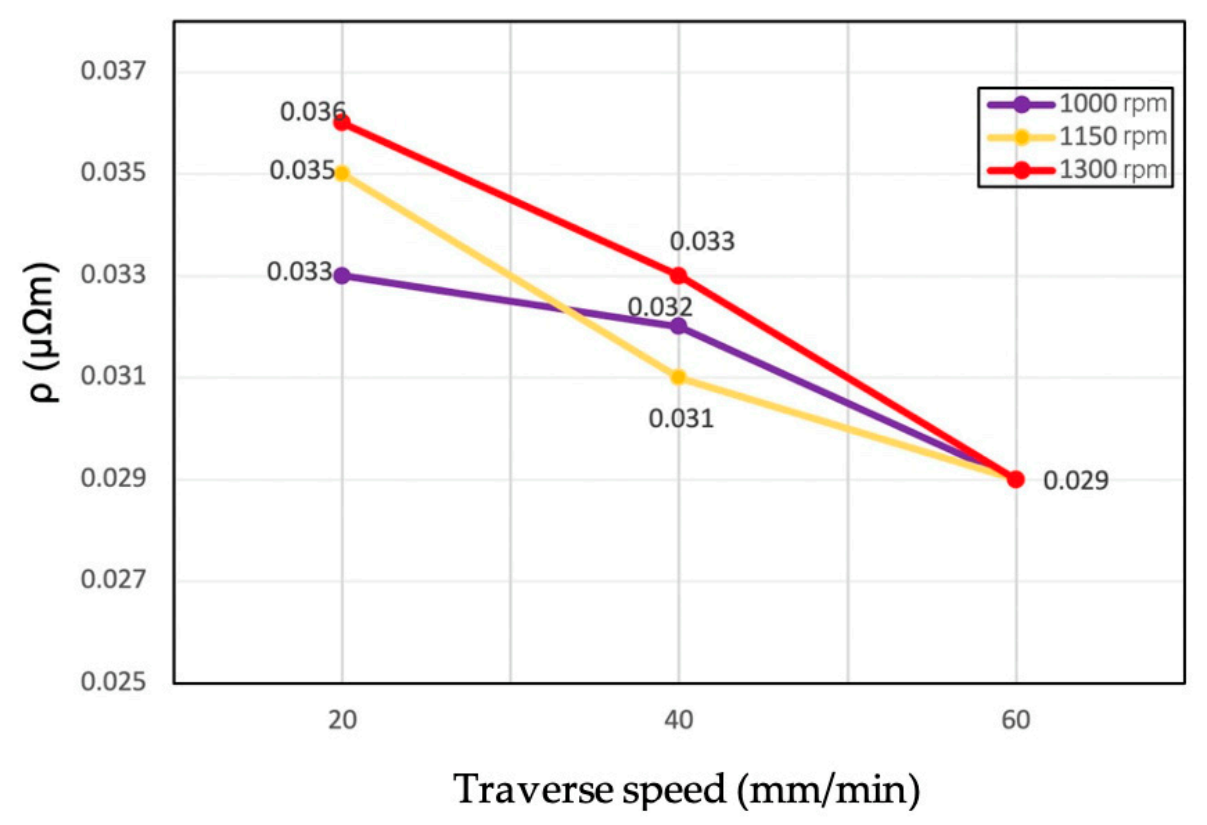

Figure 14. Effect of process parameters on resistivity values of FSW AA 6061-C11000.

As it can be observed in Figure 14, higher resistivity values were obtained with the lowest traverse speed, $20 \mathrm{~mm} / \mathrm{min}$, which resulted in the presence and greater thickening of IMCs. Average electrical resistivity values ranged from $97-98 \%$ according to the standard deviation calculated for each welding condition. These IMCs increase resistance because they present a covalent chemical bond [9,41-43]. Wei [37] studied the resistivity of $\mathrm{Al}_{2} \mathrm{Cu}$, $\mathrm{AlCu}, \mathrm{Al}_{2} \mathrm{Cu}_{3}$, and $\mathrm{Al}_{4} \mathrm{Cu}_{9}$ and found that the average resistivity of the intermetallic increases 6.7 and 4.1 times in relation to $\mathrm{Cu}$ and $\mathrm{Al}$, respectively.

Moreover, the lowest resistivity values were obtained at the highest traverse speed of $60 \mathrm{~mm} / \mathrm{min}$, and as the rotation speed increases, the resistivity increases. However, very little change is observed in the average electrical resistivity with increasing rotational speed at a constant traverse speed, this is because the temperature in the weld under these conditions is low. The average electrical resistivity increases as the temperature of the welding process increases. These results agree with those reported by Akinlabi [44], for dissimilar joints between $\mathrm{Cu}$ and 5754 aluminum alloy plates joined by FSW, in which the electrical resistivities of the joints, produced within the parameter settings considered, increased as the heat input in the weld increases. Otherwise, the electrical resistivity of the weld was not significantly affected by the values of thickness of the IMCs, because their present a relatively low average $(0.45-0.99 \mu \mathrm{m})$. This is substantiated by Braunovic [45] in the study on friction welding of $\mathrm{Al}-\mathrm{Cu}$, where he found that the increase in electrical resistivity is little when the thickness of the intermetallic layer is not greater than $2 \mu \mathrm{m}$.

Figure 15 compares the electrical conductivity of the base materials and the average electrical conductivity for each welding condition. In all the welding conditions, a good electrical conductivity was obtained, this because the thickness of the IMCs did not increase considerably. The electrical conductivity of the weld increased compared to the conductivity of aluminum, being closer to the aluminum value than to that of the copper. Since there is limited information on the electrical properties of FSW Al-Cu, it is not possible to compare the electrical conductivity results. Despite this, it can be concluded that the selection of the welding parameters tested in this investigation indicates that their application in electrical components will be feasible. 


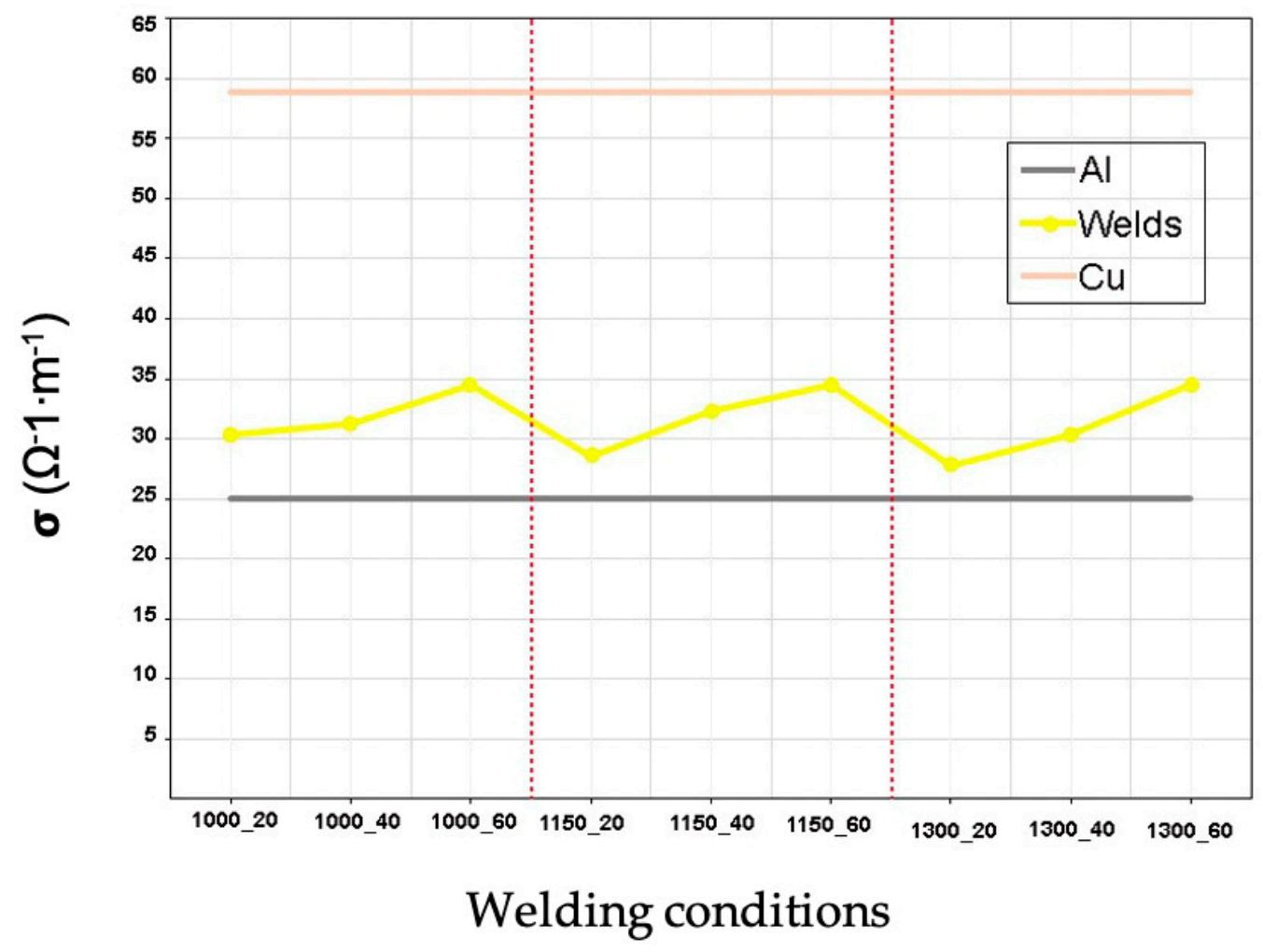

Figure 15. Effect of process parameters on the average electrical conductivity for the weld and the base materials.

\section{Conclusions}

- The range of temperatures obtained during the welding process was $288-442{ }^{\circ} \mathrm{C}$. The highest temperatures are obtained for the lowest traverse speed for any rotational speeds. The lowest temperature at $288^{\circ} \mathrm{C}$ was obtained in the welding carried out at $1000 \mathrm{rpm}$ and $60 \mathrm{~mm} / \mathrm{min}$; otherwise, the highest temperature at $442{ }^{\circ} \mathrm{C}$ was obtained in the welding performed at $1300 \mathrm{rpm}$ and $20 \mathrm{~mm} / \mathrm{min}$.

- The IMC with the greatest amount present in all the welding conditions was $\mathrm{Al}_{2} \mathrm{Cu}$, while $\mathrm{Al}_{4} \mathrm{Cu}_{9}$ was found in minor proportion. The areas TMAZ Cu-side and DXZ presented the greatest quantity of IMCs under any welding condition. In the crosssection welding, IMCs are mainly in the lower region, followed by the middle and, lastly, the upper region. The thickness of the intermetallic layers varies from 0.16 to $2.14 \mu \mathrm{m}$ and the average thickness of the IMCs is $0.66 \mu \mathrm{m}$.

- The electrical resistivities of the joints were between 0.029 and $0.036 \mu \Omega$. Higher resistivity values were obtained with the lowest traverse speed, $20 \mathrm{~mm} / \mathrm{min}$, where the IMCs are thicker due to the higher temperatures recorded during welding as the traverse speed decreased. The lowest resistivity values were obtained at the highest traverse speed of $60 \mathrm{~mm} / \mathrm{min}$.

- A little change is observed in the average electrical resistivity with increasing rotation speed at a constant traverse speed, this is because the temperature in the joints under these conditions is lower. The average electrical resistivity increases as the temperature of the welding process increases.

- The electrical conductivity of the joints increased compared to the conductivity of aluminum, being closer to the aluminum value than to that of the copper. However, the selection of the welding parameters tested in this investigation indicates that their application in electrical components will be feasible. 
Author Contributions: Conceptualization, N.A.R.-R., and D.G.-N.; Methodology, N.A.R.-R. and C.R.M.-V.; Validation, J.S.G.-V. and J.C.O.-C.; Formal Analysis, J.S.G.-V.; Investigation, D.G.-N. and N.A.R.-R.; Resources, C.R.M.-V.; Data Curation, J.G.-C.; Writing-Original Draft Preparation, N.A.R.-R. and D.G.-N.; Writing-Review \& Editing, J.S.G.-V. and C.R.M.-V.; Supervision, N.A.R.-R. All authors have read and agreed to the published version of the manuscript.

Funding: This research received no external funding.

Data Availability Statement: The data and methods used in the research are presented in sufficient detail in the document for other researchers to replicate the work.

Acknowledgments: We gratefully acknowledge CONACYT México, Tecnológico Nacional de México and Universidad Autónoma de Coahuila for the support in this investigation.

Conflicts of Interest: The authors declare no conflict of interest

\section{References}

1. Mehta, K.P.; Vishvesh, J.B. A Review on Dissimilar Friction Stir Welding of Copper to Aluminum: Process, Properties, and Variants. Mater. Manuf. Process 2016, 31, 233-254. [CrossRef]

2. Boumerzoug, Z. Joining of dissimilar materials by friction stir welding. MATEC Web Conf. 2018, 224, 01118. [CrossRef]

3. Zhang, J.; Shen, Y.; Yao, X.; Xu, H.; Li, B. Investigation on dissimilar underwater friction stir lap welding of 6061-T6 aluminum alloy to pure copper. Mater. Des. 2014, 64, 74-80. [CrossRef]

4. Safeen, M.W.; Russo Spena, P. Main Issues in Quality of Friction Stir Welding Joints of Aluminum Alloy and Steel Sheets. Metals 2019, 9, 610. [CrossRef]

5. Liu, F.C.; Dong, P. From thick intermetallic to nanoscale amorphous phase at Al-Fe joint interface: Roles of friction stir welding conditions. Scr. Mater. 2020, 191, 167-172. [CrossRef]

6. Shah, L.H.; Othman, N.H.; Gerlich, A. Review of research progress on aluminium-magnesium dissimilar friction stir welding. Sci. Technol. Weld. Join. 2017, 23, 256-270. [CrossRef]

7. Mingrun, Y.; Hongyun, Z.; Zhihua, J.; Zili, Z.; Fei, X.; Li, Z.; Xiaoguo, S. Influence of welding parameters on interface evolution and mechanical properties of FSW Al/Ti lap joints. Mater. Sci. Technol. 2019, 35, 1543-1554. [CrossRef]

8. Patel, N.P.; Parlikar, P.; Singh Dhari, R.; Mehta, K.; Pandya, M. Numerical modelling on cooling assisted friction stir welding of dissimilar Al-Cu joint. J. Manuf. Process. 2019, 47, 98-109. [CrossRef]

9. Amani, H.; Soltanieh, M. Intermetallic Phase Formation in Explosively Welded Al/Cu Bimetals. Metall. Mater. Trans. B 2016, 47, 2524-2534. [CrossRef]

10. Rajakumar, S.; Muralidharan, C.; Balasubramanian, V. Optimization of the friction-stir-welding process and tool parameters to attain a maximum tensile strength of AA7075-T6 aluminium alloy. Proc. Inst. Mech. Eng. Part B J. Eng. Manuf. 2010, 224, 1175-1191. [CrossRef]

11. Singh, R.P.; Dubey, S.; Singh, A.; Kumar, S. A review paper on friction stir welding process. Mater. Today Proc. 2020. [CrossRef]

12. Nidhi, S.; Arshad, N.S.; Zahid, A.K.; Mohsin, T.M. Material stirring during FSW of Al-Cu: Effect of pin profile. Mater. Manuf. Process. 2018, 33. [CrossRef]

13. Shankar, S.; Vilaça, P.; Dash, P.; Chattopadhyaya, S.; Hloch, S. Joint strength evaluation of friction stir welded Al-Cu dissimilar alloys. Measurement 2019, 146, 892-902. [CrossRef]

14. Carlone, P.; Astarita, A.; Palazzo, G.S. Microstructural aspects in Al-Cu dissimilar joining by FSW. Int. J. Adv. Manuf. Technol. 2015, 79, 1109-1116. [CrossRef]

15. Prangnell, P.B.; Heason, C.P. Grain structure formation during friction stir welding observed by the "stop action technique". Acta Mater. 2005, 53, 3179-3192. [CrossRef]

16. Hang, C.J.; Wang, C.Q.; Mayer, M.; Tian, Y.H.; Zhou, Y.; Wang, H.H. Growth behavior of Cu/Al intermetallic compounds and cracks in copper ball bonds during isothermal aging. Microelectron. Reliab. 2008, 48, 416-424. [CrossRef]

17. Abbasi, M.; Karimi Taheri, A.; Salehi, M.T. Growth rate of intermetallic compounds in Al/Cu bimetal produced by cold roll welding process. J. Alloys Compd. 2001, 319, 233-241. [CrossRef]

18. Kumar, N.; Yuan, W.; Mishra, R.S. Friction Stir Welding of Dissimilar Alloys and Materials. Frict. Stir Weld. Dissimilar Mater. 2015, 71-114. [CrossRef]

19. Khodir, S.A.; Ahmed, M.Z.; Ahmed, E.; Mohamed, M.R.; Abdel Aleem, H. Effect of Intermetallic Compound Phases on the Mechanical Properties of the Dissimilar Al/Cu Friction Stir Welded Joints. J. Mater. Eng. Perform. 2016, 25, 4637-4648. [CrossRef]

20. Ryl'kov, E.N.; Isupov, F.Y.; Naumov, A.A.; Panchenko, O.V.; Shamshurin, A.I. Microstructure and Mechanical Properties of Dissimilar Al-Cu Joints Formed by Friction Stir Welding. Met. Sci. Heat Treat. 2019, 60, 734-738. [CrossRef]

21. Xue, P.; Xiao, B.L.; Ni, D.R.; Ma, Z.Y. Enhanced mechanical properties of friction stir welded dissimilar Al-Cu joint by intermetallic compounds. Mater. Sci. Eng. A 2010, 527, 5723-5727. [CrossRef]

22. Milicic, M.; Gladović, P.; Bojanic, R.; Savković, T.; Stojić, N. Friction stir welding (FSW) process of copper alloys. Metalurgija 2016, 55, 107-110. 
23. Esmaeili, A.; Givi, M.K.B.; Rajani, H.R.Z. A metallurgical and mechanical study on dissimilar Friction Stir welding of aluminum 1050 to brass (CuZn30). Mater. Sci. Eng. A 2011, 528, 7093-7102. [CrossRef]

24. Huang, K.; Logé, R.E. A review of dynamic recrystallization phenomena in metallic materials. Mater. Des. 2016, 111, 548-574. [CrossRef]

25. Xue, P.; Ni, D.R.; Wang, D.; Xiao, B.L.; Ma, Z.Y. Effect of friction stir welding parameters on the microstructure and mechanical properties of the dissimilar Al-Cu joints. Mater. Sci. Eng. A 2011, 528, 4683-4689. [CrossRef]

26. Fotouhi, Y.; Rasaee, S.; Askari, A.; Bisadi, H. Effect of transverse speed of the tool on microstructure and mechanical properties in dissimilar butt friction stir welding of Al5083-copper sheets. Eng. Solid Mech. 2014, 2, 239-246. [CrossRef]

27. Muthu, M.F.X.; Jayabalan, V. Tool travel speed effects on the microstructure of friction stir welded aluminum-copper joints. $J$. Mater. Process. Technol. 2015, 217, 105-113. [CrossRef]

28. Beygi, R.; Kazeminezhad, M.; Kokabi, A.H. Microstructural Evolution and Fracture Behavior of Friction-Stir-Welded Al-Cu Laminated Composites. Metall. Mater. Trans. 2014, 45, 361-370. [CrossRef]

29. Ólafsson, D.; Vilaça, P.; Vesanko, J. Multiphysical characterization of FSW of aluminum electrical busbars with copper ends. Weld. World 2020, 64, 59-71. [CrossRef]

30. 30 Eslami, N.; Harms, A.; Henke, B.; Fricke, A.; Böhm, S. Electrical and mechanical properties of friction stir welded Al-Cu butt joints. Weld. World 2019, 63, 903-911. [CrossRef]

31. Barekatain, H.; Kazeminezhad, M.; Kokabi, A.H. Microstructure and Mechanical Properties in Dissimilar Butt Friction Stir Welding of Severely Plastic Deformed Aluminum AA 1050 and Commercially Pure Copper Sheets. J. Mater. Sci. Technol. 2014, 30, 826-834. [CrossRef]

32. Wiedenhoft, A.G.; Amorim, H.J.; Rosendo, T.S.; Tier, M.A.D.; Reguly, A. Effect of Heat Input on the Mechanical Behaviour of Al-Cu FSW Lap Joints. Mater. Res. 2018, 21. [CrossRef]

33. Saeid, T.; Abdollah-zadeh, A.; Sazgari, B. Weldability and mechanical properties of dissimilar aluminum-copper lap joints made by friction stir welding. J. Alloys Compd. 2010, 490, 652-655. [CrossRef]

34. Santosh, K.S.; Nimai, H.; Saurav, D.; Rajneesh, K. Experimental studies on AA6063-Cu dissimilar friction stir welding using Inconel 601 tool. Mater. Today Proc. 2020, 26, 180-188. [CrossRef]

35. Sharma, N.; Khan, Z.A.; Siddiquee, A.N. Friction stir welding of aluminum to copper-An overview. Trans. Nonferrous Met. Soc. China 2017, 27, 2113-2136. [CrossRef]

36. Okamoto, H.; Schlesinger, M.E.; Mueller, E.M. ASM Handbook, Volume 3: Alloy Phase Diagrams; ASM International: Materials Park, OH, USA, 2016; p. 291. ISBN 978-1-62708-070-5.

37. Wei, Y.; Li, H.; Xiao, P.; Zou, J. Microstructure and Conductivity of the Al-Cu Joint Processed by Friction Stir Welding. Adv. Mater. Sci. Eng. 2020, 1-10. [CrossRef]

38. Liu, H.J.; Shen, J.J.; Xie, S.; Huang, Y.X.; Cui, F.; Liu, C.; Kuang, L.Y. Weld appearance and microstructural characteristics of friction stir butt barrier welded joints of aluminium alloy to copper. Sci. Technol. Weld. Join. 2012, 17, 104-110. [CrossRef]

39. Seyed, V.; Hossein, A.; Mohammad, B.G. Formation and Distribution of Brittle Structures in Friction Stir Welding of AA6061 To Copper. Influ. Preheat. Mech. Mater. Sci. 2016. [CrossRef]

40. Celik, S.; Cakir, R. Effect of Friction Stir Welding Parameters on the Mechanical and Microstructure Properties of the Al-Cu Butt Joint. Metals 2016, 6, 133. [CrossRef]

41. Tan Chee, W.; Abdul Razak, D. The effects of aged Cu-Al intermetallics to electrical resistance in microelectronics packaging. Microelectron. Int. 2002, 19, 38-43. [CrossRef]

42. Zhang, J.; Wang, B.; Chen, G.; Wang, R.; Miao, C.; Zheng, Z.; Tang, W. Formation and growth of Cu-Al IMCs and their effect on electrical property of electroplated Cu/Al laminar composites. Trans. Nonferr. Met. Soc. China 2016, 26, 3283-3291. [CrossRef]

43. Won-Bae, L.; Kuek-Saeng, B.; Seung-Boo, J. Effects of intermetallic compound on the electrical and mechanical properties of friction welded $\mathrm{Cu} / \mathrm{Al}$ bimetallic joints during annealing. J. Alloys Compd. 2005, 390, 212-219. [CrossRef]

44. Akinlabi, E.T.; Madyira, D.M.; Akinlabi, S. Effect of heat input on the electrical resistivity of dissimilar friction stir welded joints of aluminium and copper. IEEE Africon'11 2011. [CrossRef]

45. Braunovic, M.; Alexandrov, N. Intermetallic compounds at aluminum-to-copper electrical interfaces: Effect of temperature and electric current. IEEE Trans. Compon. Packag. Manuf. Technol. Part A 1994, 17, 78-85. [CrossRef] 